\title{
Systemic versus cellular acclimation to temperature by poikilotherms ${ }^{1}$
}

\author{
JOHN L. ROBERTS \\ Department of Zoology, University of Massachusetts, \\ Amberst, Massachusetts, USA
}

KURZFASSUNG: Systemische versus zelluläre Temperaturakklimation bei Poikilothermen. Die Bildung nervöser, hormonaler und zirkulatorischer Systeme hat im Verlauf der Evolution durch die Entwicklung homöostatischer Feed-back-Systeme zu thermischer Unabhängigkeit vom Klima (Poikilothermie) geführt. Es lassen sich zwei Arten der Temperaturkompensation unterscheiden, die von PREcht Leistungs- und Resistenzadaptation (Thermostabilität nach Usharov) genannt werden. Bei Betrachtung des intraspezifischen Niveaus dieser Adaptationen ergeben sich mehrere ungelöste Fragen. Diese werden anhand von Vorstellungen, denen eigene Arbeiten an eurythermen Süßwasserfischen (Lepomis gibbosus, Carassius carassius) zugrunde liegen, erörtert: (1) Die genetische Basis der Leistungs- und Resistenzadaptation beruht teilweise auf unterschiedlichen Selektionsvorgängen. (2) Den Akklimationsunterschieden, die hinsichtlich der Letaltemperaturen isolierter Gewebe und Organe gefunden werden, kann oft keine ökologische Bedeutung zugeordnet werden im Gegensatz zu den entsprechenden Verhältnissen im Ganztier. Der letztgenannte Gesichtspunkt basiert auch auf UsHAkovs Studien sowie den Experimenten von BasLow \& Nigrelur, nach denen die Temperaturgrenzen der Cholinesterase-Aktivität des Gehirns von Fundulus teilweise homöostatische Regulationen der Leistungsadaptation widerspiegeln. Meines Erachtens erfordert eine Beantwortung dieser Fragen die Erfassung des relativen Ausmaßes systemischer Wechselwirkungen bei verschiedenen größeren Tiergruppen und eine Untersuchung der Adaptationseigenschaften verschiedener Zelltypen lebender Tiere, in welchen die zellulären Aktivitäten systemischen Wechselwirkungen unterworfen sind.

\section{INTRODUCTION}

Avoidance of being at the mercy of temperature has resulted in the evolution of a great variety of thermal adaptations among poikilotherms which act to ensure reproduction during the most fayorable season of the year. Two general categories of these climatic compensations in individual animals have been widely recognized and termed by PRECHT (1955), capacity and resistance adaptations. The first of these categories implies that temperature changes induce metabolic rate controls in the sense of providing homeostasis in the routine expenditure of energy over wide temperature ranges. The

1 Dedicated to Prof. Dr. H. PRECHT for his continuing insight into devising means and a philosophy to show how and why the old view that a cold-blooded animal is a "Spielball der Umgebungstemperatur" is no longer acceptable. 
second suggests that tolerated upper and lower thermal limits also shift seasonally, again implying that metabolic compensations occur but at different levels of organization in the animal. Despite evidence that these two types of adaptation sometimes correlate within individuals seasonally, exceptions are numerous so that many questions have arisen for which we have only partial answers and some disagreement as to how the answers should be interpreted. Therefore, as a physiological ecologist, I should like to consider three related questions which have come to mind as a result of my own studies with fresh-water fishes and attempt to answer in detail only the first.

(1) Has there been an evolutionary trend toward systemic dominance in the physiological expression of thermal compensations in multicellular animals over primitive, generalized direct responses of cells to temperature? Furthermore, is this systemic dominance typically under the primary control of a few cells in some sort of unidentified thermal compensatory center in the central nervous system?

(2) Are the genetic backgrounds for phenotypic expression in whole animals of capacity and resistance adaptations based in part upon different modes of environmental selection?

(3) Can ecological significance be attached to acclimation differences found in the thermal limits of isolated tissues and organs as seems rational for limits differences observed with entire donor animals?

All three of these questions have been resolved from a basic assumption that the invention of multicellularity and subsequent systemic elaborations, chiefly of nervous, hormonal and circulatory systems, has led to an increasing degree of thermal independence from climate for poikilotherms by the evolution of feedback homeostasis. One convenient way to visualize this stream of events in evolutionary history is to erect a sequence as follows, where the major evolutionary steps of interest are related to probable levels of integration and their advantages or limitations:

UNICELL
MULTICELL

When such relationships are considered, it is difficult not to give the answer yes to my first question. This is especially so of animals in poikilothermal groups notable for high levels of motor activity in feeding, predation avoidance and reproduction for they also have the associated requirements of high circulation rates and rapid neuronal coordination.

Before passing to the two remaining questions, I would like to present my own experimental results with fishes and those of others to document the contentions implicit in the first question. . 


\section{MATERIALS AND METHODS}

Animals care and feeding. Fishes used were the pumkinseed or sunfish, Lepomis gibbosus (L) at Amherst, Massachusetts and the carp, Carassius carassius (L) (Syn. Carassius vulgaris Nils.) at Kiel, Germany. The sunfish were obtained by seining from ponds and streams in the Amherst area and were presumed to be representatives of native populations. The carp used at Kiel, were purchased from commercial, freshwater fishermen at Preetz and Hohenwestedt in Schleswig-Holstein and, like most fresh-water fishes of Europe, their line of species relationships is confusing due to long established management and breeding. Confirmation of the species identification as C. carassius was very kindly given by Drs. P. BlažKa, Prague; R. KändLer, Kiel; and U. LIEDER, Berlin-Friedrichshagen. Sunfish were fed three times each week on a wellblended, one to one mixture of liver brei and powdered dog chow which was kept deep frozen $\left(-20^{\circ} \mathrm{C}\right)$ until use. This was readily accepted once the fish were trained away from their natural, live-food diet by introducing into each of the tanks containing new fish, one fish experienced in feeding upon the artifical diet. The feeding of carp proved to be simpler, for they readily accepted the daily feedings of a mixture of dry oatmeal and dried daphnia from the first day on which they were brought into the laboratory. The feeding schedule was suspended on the day before placement of fish into the respiration chambers or dissection of animals for studies with their tissues to be certain of working with fish in a postabsorbative, starving condition.

Daylengths selected and termed long and short day (Standard Time) were respectively, 15 and 9 hours for sunfish at Amherst and 17 and 7 hours for carp at Kiel. The adaptation photoperiods ( 30 foot candles, aquarium surface) were maintained at least 40 days before animals were used in the various experiments. In most cases, the fish were simultaneously acclimated to $20 \pm 0.5^{\circ} \mathrm{C}$ during this initial period of daylength control. Closer control $\left( \pm 0.02^{\circ} \mathrm{C}\right.$ ) was maintained in water baths containing the apparatus for the measurements with whole fish. Periods for thermal acclimation of the fish varied from a minimum of 3 days for a change in temperature of $5^{0} \mathrm{C}$ to a minimum of 2 weeks for a change of $15^{\circ} \mathrm{C}$.

Respiration of $\mathrm{f}$ is h. Rates of oxygen uptake by fish were established as $\mathrm{ml} / \mathrm{kg} / \mathrm{hr}$, wet weight from the difference between the oxygen content of the water supplied to a single fish chamber and that flowing out of the chamber at a precisely known volume in one hour. The outflow samples of water were collected in bottles from chambers containing fish and one chamber without a fish (water supply sample) for analysis of dissolved oxygen content by the unmodified Winkler method or with the use of a dissolved oxygen meter (Southern Analytical Ltd., type. A 1672). These samples were always taken within 3 hours either side of noon-day to avoid possible alterations in levels of respiration relating to endogenous daily rhythms of activity and shodk reactions to on-off switching of lights. The exact time of sampling was varied, but was done when the fish were quiet, as judged by polarographic monitoring of their oxygen uptake (ROBERTs 1964). A period of adaptation of 24 hours to the respiration vessels always seemed sufficient with the carp to obtain consistent rates of oxygen uptake. In contrast, sunfish routinely requited quieting periods of 3 days. Flow-rate regulation of water passing through the system was maintained with lengths of capil- 
lary tubing attached to the inflow tubes in the rubber stoppers of the sampling bottles at a constant head pressure of 30 inches of water. The head pressure was maintained to the supply manifold of the system by a spillway device equipped with particle filters and aerators to which water was delivered in excess of that required (Blazka 1958, KRÜGER 1961, ROBERTS 1964).

Respiration of tis sues. Respiration rates of gill and muscle tissues have been determined for $C$. carassius and of brain and gill for L. gibbosus by standard Warburg manometry at various temperatures. The saline suspending medium used was that previously employed (ROBERTS 1964) containing either $2.0 \mathrm{~g} / 1$ sodium succinate and $2.5 \mathrm{~g} / 1$ glucose (carp) or $3.18 \mathrm{~g} / 1$ sodium pyruvate, $0.1 \mathrm{~g} / 1$ malic acid and $2.5 \mathrm{~g} / 1$ glucose (sunfish). Before use, $10 \mathrm{ml}$ of $\mathrm{M} / 15$ buffer was added per $90 \mathrm{ml}$ of the medium to give a final $\mathrm{pH}$ of 7.4 . With carp, phosphate buffer was used but, was replaced by Tris buffer in the sunfish experiments to minimize possible inhibitory effects of high phosphate.

Finely-cut brain and muscle were prepared for manometry by forcing small blocks of tissue through the small openings $(0.5 \times 1.0 \mathrm{~mm})$ of a screen-like, electric-razor head (Braun, Rasierblatt) under the pressure of a sharp scalpel scraped across its surface. The gills were cut free from the bony arches and segmented into pieces of about $5 \mathrm{~mm}$ length. Each of the samples prepared was weighed on a tared strip of polyethylene and dropped into a Warburg flask ( $15 \mathrm{ml}$ size). Each sample was then rinsed free of the plastic strip into the $3 \mathrm{ml}$ of medium used in the respiration vessel, and the strip was removed. The samples ranged in wet weight from 50 to $100 \mathrm{mg}$ for brain and gill, and from 200 to $250 \mathrm{mg}$ for muscle. The gill and muscle tissue samples were prepared in duplicate, but usually the brains removed from the fish used in the experiments were of a size sufficient for only a single sample.

Rates of oxygen uptake, as $\mathrm{mm}^{3} / \mathrm{mg}$, wet $\mathrm{wt} / \mathrm{h}$, were established from four interval manometer readings during the stable period following equilibration (20 min). Intervals ranged from 10 minutes at $25^{\circ} \mathrm{C}$ to 20 minutes at $10^{\circ} \mathrm{C}$. In cases when 2,4dinitrophenol (DNP) was added to the main chambers from the vessel side-arms (sunfish only), to give a final concentration of $10^{-4} \mathrm{M}, \mathrm{DNP}$, those interval readings were deleted so that respiration-rates of tissues with DNP were established from the following 4 intervals. Because muscle usually showed a decline in respiratory intensity with time, rates for this tissue were obtained from the hour-long period beginning with the second, interval manometer reading (10 min). Average values for the respiration of gill and muscle tissues were based on the higher of the duplicated samples prepared from each fish.

\section{RESULTS AND DISCUSSION}

Usually it is found that when respiration rates of fishes are measured at a series of acclimation temperatures, the occurence of homeostatic compensations in metabolism will be apparent in that values of $Q_{10}$ determined from these rates will be less than 2. In terms of PRECHT's adaptation types this will be the case for types 3 (partial), 2 (ideal) or 1 (supra optimal). 
Three illustrative cases are given in Table 1 where the data for both whole fish and their tissues has been adequate for calculation of $\mathrm{Q}_{10}$ values and adaptation types. These results for two eurythermal species and one stenotherm, the rainbow trout, are given together (Table 1) to illustrate several characteristics of capacity adaptations

Table 1

Oxygen consumption by fresh-water fishes and their tissues at acclimation temperatures.

Probable adaptation types follow the schema of PRECHT (1950)

\begin{tabular}{|c|c|c|c|c|}
\hline $\begin{array}{c}\text { Animal } \\
\text { and } \\
\text { tissue }\end{array}$ & $\begin{array}{l}\text { Acclimation } \\
\text { and test } \\
\text { temp., }{ }^{\circ} \mathrm{C}\end{array}$ & $\begin{array}{c}\mathrm{O}_{2} \text { uprake } \\
\text { as } \mathrm{mm}^{3} / \mathrm{g} / \mathrm{h} \\
\text { wet }=\mathrm{w}, \mathrm{dry}=\mathrm{d}\end{array}$ & Q10 & $\begin{array}{l}\text { Adaptation } \\
\text { type }\end{array}$ \\
\hline $\begin{array}{l}\text { Carassius auratus } \\
\text { (FREEMAN 1950) }\end{array}$ & $\begin{array}{l}12 \\
20 \\
27\end{array}$ & $\begin{array}{r}76 \mathrm{w} \\
98 \mathrm{w} \\
147 \mathrm{w}\end{array}$ & $\begin{array}{l}1.4 \\
1.8\end{array}$ & 3 \\
\hline Brain brei & $\begin{array}{l}12 \\
20 \\
27\end{array}$ & $\begin{array}{l}200 \mathrm{w} \\
320 \mathrm{w} \\
399 \mathrm{w}\end{array}$ & $\begin{array}{l}1.8 \\
1.4\end{array}$ & 3 \\
\hline $\begin{array}{l}\text { (EKBERG 1958) } \\
\text { Gill filaments }\end{array}$ & $\begin{array}{l}10 \\
30(\text { at } 26)\end{array}$ & $257 \mathrm{~d}$ & 1.6 & 3 \\
\hline Liver brei & $\begin{array}{l}10 \\
30\end{array}$ & $\begin{array}{r}621 \mathrm{~d} \\
1410 \mathrm{~d}\end{array}$ & 1.5 & 3 \\
\hline $\begin{array}{l}\text { Salmo gairdneri } \\
\text { (Evans et al. 1962) }\end{array}$ & $\begin{array}{r}8 \\
16\end{array}$ & $\begin{array}{r}73 \mathrm{w} \\
134 \mathrm{w}\end{array}$ & 2.1 & $\begin{array}{c}3 \\
\text { (poor) }\end{array}$ \\
\hline Brain brei & $\begin{array}{r}8 \\
16\end{array}$ & $\begin{array}{l}532 \mathrm{w} \\
521 \mathrm{w}\end{array}$ & -1.0 & 2 \\
\hline Gill brei & $\begin{array}{r}8 \\
16\end{array}$ & $\begin{array}{l}255 \mathrm{w} \\
496 \mathrm{w}\end{array}$ & 2.3 & 4 \\
\hline Liver brei & $\begin{array}{r}8 \\
16\end{array}$ & $\begin{array}{l}400 \mathrm{w} \\
348 \mathrm{w}\end{array}$ & -1.1 & 2 \\
\hline $\begin{array}{l}\text { Lepomis gibbosus } \\
\text { (ROBERTS 1964) }\end{array}$ & $\begin{array}{l}10 \\
20\end{array}$ & $\begin{array}{l}37 \mathrm{w} \\
53 \mathrm{w}\end{array}$ & 1.4 & $\stackrel{2}{2}\left(10^{0}-17.5^{0}\right)$ \\
\hline Brain brei & $\begin{array}{l}10 \\
20\end{array}$ & $\begin{array}{l}371 w \\
561 w\end{array}$ & 1.5 & $\begin{array}{c}3 \\
\text { (poor) }\end{array}$ \\
\hline Gill filaments & $\begin{array}{l}10 \\
20\end{array}$ & $\begin{array}{l}201 \mathrm{w} \\
334 \mathrm{w}\end{array}$ & 1.7 & 4 \\
\hline
\end{tabular}

among fishes. One of these is that good compensatory ability usually correlates with eurythermy in habitat selection. Although it is probably still too soon to claim this as a generalization on the basis of documented evidence, it is a generally held view (WrNBERG 1956, PrECHT 1958). On the other hand, the extensive array of data for thermal tolerances of North American fishes from salmonoides to the brown bull-head presented by BRETT (1956), leaves no doubt that the generalization applies for resistance adaptations. 
Another feature which I have previously reported is that the thermal range for nearly perfect homeostasis (type 2) by sunfish is limited, between $10^{\circ}$ and $17.5^{\circ} \mathrm{C}$, but modifiable by photoperiod control. Above and below these temperatures little compensation is evident ( $Q_{10}$ values 2.0 or larger). Since preparing that report, other cases showing plateauing over small temperature ranges have come to my attention (STROGANOV 1956, WINBERG 1956). A third consideration, which is of particular relevance to this discussion, is that there are often striking differences between the expressions of

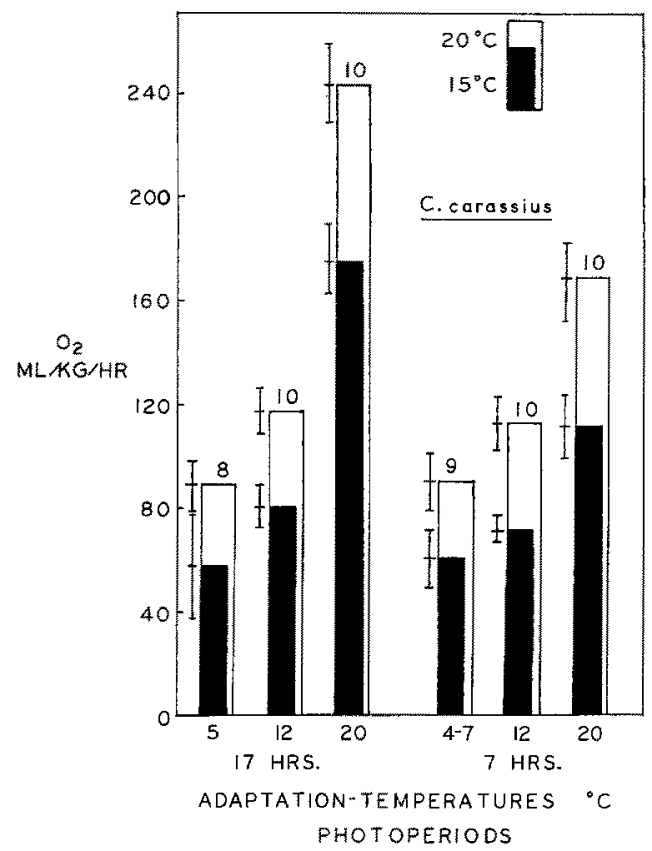

Fig. 1: Respiration of crucian carp, C. carassius, at test temperatures of $15^{\circ}$ (solid bars) and $20^{\circ} \mathrm{C}$ (open bars) at various acclimation temperatures and adaptation photoperiods. Number of determinations shown above open bars (fish per determination, $1-4$ ). Plus and minus 2 standard errors of means (95 percent confidence limits) shown to the left of each bar. (Modified from RoberTs 1961)

metabolic compensations found in whole animals and those in their isolated tissues. For the three cases in Table 1, a type 3 response has been found for the goldfish and its tissues, brain gill and liver. It is likely that the low $Q_{10}$ value for the respiration of goldfish at $12^{\circ}$ and $20^{\circ} \mathrm{C}$ is exaggerated by Freeman's high value for the acclimated rate at $12^{\circ} \mathrm{C}$ (see FRY \& HART 1948). The other eurytherm, the sunfish, despite perfect acclimation (type 2) between $10^{\circ}$ and $17.5^{\circ} \mathrm{C}$ seems to indicate a slight type 3 compensation (statistically unsupportable) for the two tissues listed and none at all in muscle. Results with rainbow trout contrast markedly, for there is evidence of perfect acclimation in brain and liver tissues, none in gill and very little in entire fish. The authors (EvANs, et al. 1962) conclude that the slight compensatory effect seen in the whole fish may be due to tonic effects of thermally compensated brain tissue. How- 
ever, it seems to me that the $Q_{10}$ value calculated from the mean acclimated rates at $8^{0}$ and $16^{\circ} \mathrm{C}$ is too high (2.1) to indicate a significant functional compensation. I reported a still more paradoxical case in 1961 and would like to add further data at this time.

During my stay at Kiel (1959-60) at the laboratory of Professor PRECHT, studies of oxygen consumption by crucian carp, C. carassius, and selected tissues (brain, muscle) were carried out following adaptation of fish to 3 acclimation temperatures and photoperiods of 7 and 17 hours. The results with whole fish are shown in Figure 1 essentially

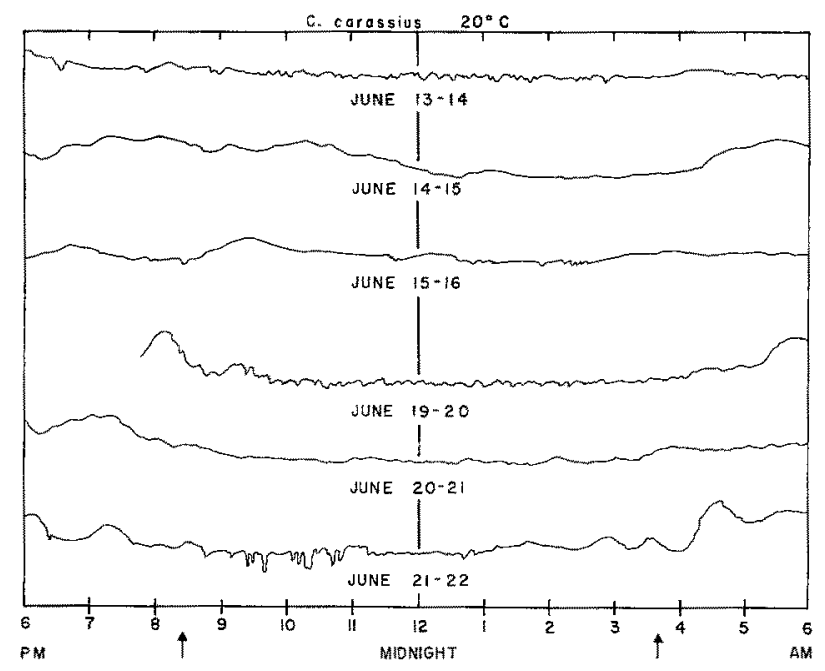

Fig. 2: Polarograph records of the respiration of individual crucian carp, C. carassius, acclimated and tested at $20^{\circ} \mathrm{C}$ (17-hour photoperiod) in relation to daily light and dark periods. Scales of respiration level are relative; deflections upward represent increases in oxygen uptake. Arrows indicate sunset and sunrise times. Time scale corrected to Greenwich meridian (BERGEDORFF)

as reported (RoBERTS 1961) with additional data for carp adapted to $5^{\circ} \mathrm{C}$, and a $17-$ hour day. Although a highly significant photoperiod effect (long day stimulation) was found only at $20^{\circ} \mathrm{C}$, the most important feature which I wish to stress is the inverse effect of temperature upon whole animal respiration (type 5). Arguments for considering the photoperiod responses of crucian carp to be systemically mediated have been presented earlier (RoBERTs 1964).

The inverse effect in carp has been considered to be a behavioral adaptation which involves a reduction in activity, which $I$ feel is necessary to permit abandonment of usual activities and entry into hibernation during winter, perhaps under anaerobic conditions within the mud of pond bottoms (ROBERTS 1961; see also BLAžKA 1958). The basis for this view was obtained by calculating day and night respiration rates at $20^{\circ} \mathrm{C}$ from polarograph recordings such as shown in Figure 2. These day and night rates are shown in Table 2 along with percentage differences as between rates before and after darkness. From this analysis it can be seen that absolute reductions in respi- 
ration levels of all groups as well as significant proportional reductions - more by fish acclimated to $20^{\circ}$ than by fish acclimated at $10^{\circ} \mathrm{C}$-occur in the degree of expression of the inverse compensation after dark when compared to daytime. That is to say that

Table 2

Influence of daylight and darkness upon oxygen uptake by Carassius carassius at $20^{\circ} \mathrm{C}$ following adaptation to different photoperiods and temperatures. Plus and minus 2 standard errors of means (95 percent confidence limits) are shown in brackets in this and subsequent tables. Respiration rates calculated from polarographic recordings

\begin{tabular}{|cccccc|}
\hline $\begin{array}{c}\text { Photoperiod } \\
\text { hours }\end{array}$ & Number & $\begin{array}{c}\text { Acclimation } \\
\text { temp., }{ }^{\circ} \mathrm{C}\end{array}$ & $\begin{array}{c}\text { Day rate } \\
\mathrm{ml} / \mathrm{kg} / \mathrm{h}\end{array}$ & $\begin{array}{c}\text { Night rate } \\
\mathrm{ml} / \mathrm{kg} / \mathrm{h}\end{array}$ & $\begin{array}{c}\text { Night rate } \\
\text { as per cent } \\
\text { day rate }\end{array}$ \\
\hline 7 & 9 & 20 & $\begin{array}{c}149 \\
(142-156)\end{array}$ & $\begin{array}{c}93 \\
(80-105)\end{array}$ & 62 \\
7 & 9 & 10 & $\begin{array}{c}124 \\
(108-140)\end{array}$ & $\begin{array}{c}110 \\
(99-120)\end{array}$ & 88 \\
17 & 9 & 20 & $\begin{array}{c}196 \\
(156-235)\end{array}$ & $\begin{array}{c}123 \\
(98-148)\end{array}$ & 63 \\
17 & 12 & 12 & 108 & 90 & 83 \\
& & & $(82-134)$ & $(72-107)$ & \\
\hline
\end{tabular}

Table 3

Rates of respiration of gill bars and muscle brei of Carassius carassius at $25^{\circ} \mathrm{C}$ in a glucosesuccinate saline following adaptation of the fish to short and long photoperiods and to various acclimation temperatures

\begin{tabular}{cccccc|}
\hline $\begin{array}{c}\text { Photoperiod } \\
\text { hours }\end{array}$ & $\begin{array}{c}\text { Acclimation } \\
\text { temp., }{ }^{0} \mathrm{C}\end{array}$ & $\begin{array}{c}\text { Gill } \\
\text { number }\end{array}$ & $\begin{array}{c}\text { Gill rate } \\
\mathrm{mm}^{3} / \mathrm{g} / \mathrm{h}\end{array}$ & $\begin{array}{c}\text { Muscle } \\
\text { number }\end{array}$ & $\begin{array}{c}\text { Muscle rate } \\
\mathrm{mm}^{3} / \mathrm{g} / \mathrm{h}\end{array}$ \\
\hline 7 & $4-7$ & 18 & $\begin{array}{c}701 \\
(629-773)\end{array}$ & 20 & $\begin{array}{c}290 \\
(261-319) \\
201\end{array}$ \\
7 & 20 & 22 & $\begin{array}{c}548 \\
(497-599) \\
(179-225)\end{array}$ & 22 & 257 \\
17 & 5 & 10 & $\begin{array}{c}618 \\
(556-684)\end{array}$ & 10 & $(233-281)$ \\
17 & 20 & 13 & $\begin{array}{c}489 \\
(457-521)\end{array}$ & 146 & $(172-200)$ \\
\hline
\end{tabular}

the magnitude of the inverse acclimation of respiration is so reduced when the fish are kept in darkness, that statistically no compensations relating to acclimation temperature (or photoperiod) are detectable (type 4).

That the inverse response in carp is largely under systemic control, becomes an even more attractive suggestion when respiration rates of tissues are examined at $25^{\circ} \mathrm{C}$ (Table 3). First, I should mention that the data shows no obvious effects relatable to the photoperiod sensitivity found in entire fish. On the other hand, a good type 3 response is evident in both brain and muscle tissues. Differences in adaptation types 
between the tissues and the donor carp seem to present a paradox. Yet, the possibility exists that systemic controls were evolved in $C$. carassius to meet special requirements for overwintering and may be adequate to override the compensatory responses found in isolated brain and muscle tissues (ROBERTs 1964).

I would like to present one more experimental series of tissue respiration studies with brain and gill of $L$. gibbosus but, this time following uncoupling with DNP. A portion of the data prior to uncoupling is given in Table 1 where the acclimation and test temperatures used were identical $\left(10^{\circ}\right.$ and $\left.20^{\circ} \mathrm{C}\right)$. Additionally, respiration determinations were made for a third group at a test temperature of $15^{\circ} \mathrm{C}$ also using tissues from the $10^{\circ}$ and $20^{\circ} \mathrm{C}$ acclimation groups. The suspending medium used was a glucose-pyruvate-malate saline, which contrasts to a similar series reported in 1964 (test temperature $25^{\circ} \mathrm{C}$ ) in which a glucose-succinate saline was employed. The pyruvatemalate substitution has proven to give reasonable levels of respiration. Following the addition of DNP, greater degrees of uncoupling have been obtained than with the succinate medium. This probably is due to elimination of the short-cycling effect in succinate oxidation by a flavin-linked dehydrogenase. Although incomplete, I feel that the results give direction to my future experiments along this line.

Among the features of this recent series is that the type 3 trend in tissue compensations of both brain and gill ( $10^{\circ}$ and $20^{\circ} \mathrm{C}$ acclimated fish) is upset by uncoupling and resembles afterward a type 5 response. This was observed previously for brain but not gill (RoBerTs 1964). A second curious response was the consistently greater uncoupling found in tissues removed from $20^{\circ} \mathrm{C}$ acclimated fish at test temperatures of $15^{\circ}$ and $20^{\circ} \mathrm{C}$ when compared to results at $10^{\circ}$ and $15^{\circ} \mathrm{C}$ for tissues taken from the cold-acclimated animals. Again this was found to parallel the earlier results for brain but not gill tissue. The obvious explanation is that uncoupling breaks some link in electron transport which somehow is subject to thermal compensation. However, I hesitate to speculate further except to point out the possibility that compensations may alter the quantitative availability of pyridine nucleotides in linking carbohydrate degradation to electron transfer.

It is evident from results which have been recounted and the far more extensive results of others (see Prosser 1962, PRECHT 1964) that it is difficult to assess quantitatively the relative contributions of cellular versus systemic level adjustments in the sense of compensations by whole animals to changes in thermal environments. Yet, the urgency for increasing efforts to do this became evident in 1963 at Leningrad (International Symposium on Cytoecology) when ecological interpretations derived from studies on resistance adaptations in isolated cells and tissues of poikilotherms were challenged by Russian biologists (see Ushakov 1964, SCHLreper 1966, UshaKov 1966).

One aspect of the challenge seems not only to center upon the ecological validity of resistance adaptations seen in isolated systems when out of context with the donor animals but, to capacity adaptations as well. The reason for this is that the two adaptation categories often seem to be functionally linked. Recently, PRECHT (1964) reiterated this relational view and also pointed out the need to differentiate between direct effects and side effects in the expression of capacity and resistance adaptations. In this regard, an elemental but difficult problem is to select adaptation indices which do not 
lead to spurious ecological correlations. The ingenious experiments of BAsLow \& NIGRELLI (1964) illustrate this point very well, for they have found evidence that fixed thermostability differences occur in the brain cholinesterases from a variety of warm and cold-water fishes. These correlate with the thermal environments of the various fishes and provide another case of interspecific variation (see also Usнakov 1964, Table 5). In contrast, no evidence was found for similar differences in thermostabilities of enzyme preparations from different populations of Fundulus beteroclitus except as related to previous thermal history or body weight (intraspecific comparison). However, upon further examination it became apparent to BASLOw \& NIGRELL that changes observed in heat stability of the brain cholinesterase from Fundulus acclimated to different temperatures represented a secondary effect. The primary effect proved to be a capacity adaptation for homeostasis in enzymatic activity of a type 2 capability.

In concluding, I should like to state that full answering of questions such as I have presented will require further determinations of the relative degrees of elaborations of systemic interactions in different, major animal groups. There is also need to devise means to characterize adaptations of cell types within living animals in which cellular activities are subject to systemic interactions. The profit of such approaches with fishes is already apparent in the results from a number of laboratories (HIckMaN, Edmonton; Precht, Kiel; Prosser, Urbana; Tsukuda, Osaka).

\section{SUMMARY}

1. This discussion is based upon the assumption that the invention of multicellularity and the subsequent elaboration of nervous, hormonal and circulatory systems has led to an increasing degree of thermal independence from climate for poikilotherms by the evolution of homeostatic feedback systems.

2. Systemic dominance in homeostasis has been considered in relation to metabolic compensations in the respiration of the sunfish, Lepomis gibbosus, the crucian carp, Carassius carassins, and selected tissues (brain, gill, muscle) following adaptation to various temperatures and photoperiods. Uncoupled respiration has also been examined in sunfish brain and gill tissues following treatment with 2, 4-dinitrophenol. A poor type 3 trend (statistically unsupported) was found to be upset by uncoupling and was followed by a probable type 5 response.

3. Comparisons were made (at $20^{\circ} \mathrm{C}$ ) between day and night respiration rates of crucian carp acclimated to $5^{\circ}, 12^{\circ}$ and $20^{\circ} \mathrm{C}$. These suggest that the inverse compensation of the fish (type 5 ) is a behavioral adaptation to special winter conditions, perhaps hibernation.

4. Some of the problems concerned with deriving ecological meaning from experiments on resistance and capacity adaptations in isolated cells and tissues have been discussed. The suggestion is made that means be developed to expand studies in which adaptation characteristics of cell types can be examined within living animals. 


\section{ACKNOWLEDGMENT}

This investigation was supported in whole by Public Health Service Research Grant GM 06377 from the Division of General Medical Sciences.

\section{LITERATURE CITED}

Baslow, M. H. \& Nigrelli, R. F., 1964. The effect of thermal acclimation on brain cholinesterase activity of the killifish, Fundulus heteroclitus. Zoologica, N.Y. 49, 41-51.

BlAžKa, P., 1958. The anaerobic metabolism of fish. Physiol. Zool. 31, 117-12.8.

BRETT, J. R., 1955. Some principles in the thermal requirements of fishes. Q. Rev. Biol. 31, $75-87$.

BulLOCK, T. H., 1955. Compensation for temperature in the metabolism and activity of poikilotherms. Biol. Rev. 30, 311-342.

EkBERG, D. R., 1958. Respiration in tissues of goldfish adapted to high and low temperatures. Biol. Bull. mar. biol. Lab., Woods Hole 114, 308-316.

Evans, R. M., Purdie, F. C. \& Hickman, C. P., Jr., 1962. The effect of temperature and photoperiod on the respiratory metabolism of rainbow trout (Salmo gairdneri). Can. J. Zool. 40, 107-118.

FRY, F. E. J. \& HART, J. S., 1948. The relation of temperature to oxygen consumption in the goldfish. Biol. Bull. mar, biol. Lab., Woods Hole 94, 66-77.

FREEMAN, J. A., 1950. Oxygen consumption, brain metabolism and respiratory movements of goldfish during temperature acclimation. Biol. Bull. mar. biol. Lab., Woods Hole 99, $416-424$

KRÜGER, G., 1962. Über die Temperaturadaptation des Bitterlings (Rhodeus amarus BLoch). Z. wiss. Zool. 167, 87-104.

PrechT, H., 1958. Concepts of the temperature adaptation of unchanging reaction systems of cold-blooded animals. In: Physiological adaptation. A symposium held Sept. 5-6, 1957 at the Mar. Biol. Lab., Woods Hole, Mass. Ed. by C. L. Prosser. Am. Physiol. Soc., Washington, D.C., 50-78.

- 1964. Uber die Bedeutung des Blutes für die Temperaturadapration von Fischen. Zool, $J b$. (Allg. Zool. Physiol. Tiere) 71, 313-328.

- Christophersen, J. \& Hensel, H., 1955. Temperatur und Leben. Springer, Berlin, 514 pp.

Prosser, C. L., 1962. Acclimation of poikilothermal vertebrates to low temperatures. In: Comparative physiology of temperature regulation. 2. Proc. of the Symposium on arctic biology and medicine. Ed. by J. P. Hannon \& E. Viereck. Arctic Aeromedical Lab., Fr Wainright, Alaska, 1-44.

RoBerts, J. L., 1961. The influence of photoperiod upon thermal acclimation by the crucian carp, Carassius carassius (L.). Zool. Anz. (Suppl. Bd.) 24, 73-78.

- 1964. Metabolic responses of fresh-water sunfish to seasonal photoperiods and temperatures. Helgoländer wiss. Meeresunters. 9, 459-473.

SCHLIEPER, C, 1966. Genetic and nongenetic cellular resistance adaptation in marine invertebrates. Helgoländer wiss. Meeresunters. 14, 482-502.

Stroganov, N. S., 1956. Physiological adaptability of fish to the temperature of the surrounding medium. Transl. from Russian by M. Roublev. Israel Progr. for Scientific Transl. (for Nat. Sci. Found., Wash., D.C.), Jerusalem, 108 pp.

Ushakov, B. P., 1964. Thermostability of cells and proteins of poikilotherms and its significance in speciation. Pbysiol. Rev. 44, 518-560.

- 1966. The problem of associated changes in protein thermostability in the process of speciation. Helgoländer wiss. Meeresunters. 14, 466-481.

WinBerg, C. G., 1956. Rate of metabolism and food requirements of fishes. Transl. Ser, Fish. Res. Bd. Can. 194, 1-253, 1960 (Naud. Trudy Belorussk. Gosudarstr. Uninv. im. V. I. Lenina, Minsk). 


\section{Discussion following the paper by ROBERTS}

KINNE: In the evaluation of quantitative aspects of non-genetic adaptations, we have thus far largely neglected one important parameter: the time element. The maximum amount of an acclimation in regard to a given temperature condition may be attainable only if the test individuals were born and raised under the conditions in question. But even if we begin our experiments with adult individuals, the time element needs specific attention. If we compare, for example, the gain in heat resistance of fish exposed for 10 days to constant temperatures of $10^{\circ}$ and $20^{\circ} \mathrm{C}$ respectively, the differences observed may turn out to be a function of exposure time (Fig. $D_{1}$ ). The time course of the acclimation process - possibly also the maximum amount of acclimation attainable - is likely to be different at both test temperatures. I suggest therefore that in regard to quantitative comparisons, it would be better to talk about fish that have achieved 20,80 or $90 \%$ of the total amount of acclimation attainable under the environmental circumstances specified rather than to refer to warm- or cold-acclimated individuals.

ROBERTS: I can only agree with your argument and assume that when one speaks of acclimated animals, these are animals which have attained near maximal adjustment to the prevailing thermal conditions. In my own work, $I$ have not obtained curves for metabolic activities versus time such as you illustrate. I feel reasonably sure that the $90+$ percent level of acclimation is reached in one week by sunfish above $15^{\circ} \mathrm{C}$, and within two weeks at lower temperatures. Also, when the magnitude of temperature change for a particular experiment is to be large, such as a shift between $10^{\circ}$ and $20^{\circ} \mathrm{C}$ or the reverse, I have made it a practice to shift the temperature in at least two stages separated in time by a day or so in order to avoid shock effects. Further adjustments have not been found beyond adaptation periods of two weeks at temperatures below $15^{\circ} \mathrm{C}$.

KnNE: Towards the beginning of your very interesting paper you made a general statement which $I$ would like to recall here. You said that your review is based upon the assumption

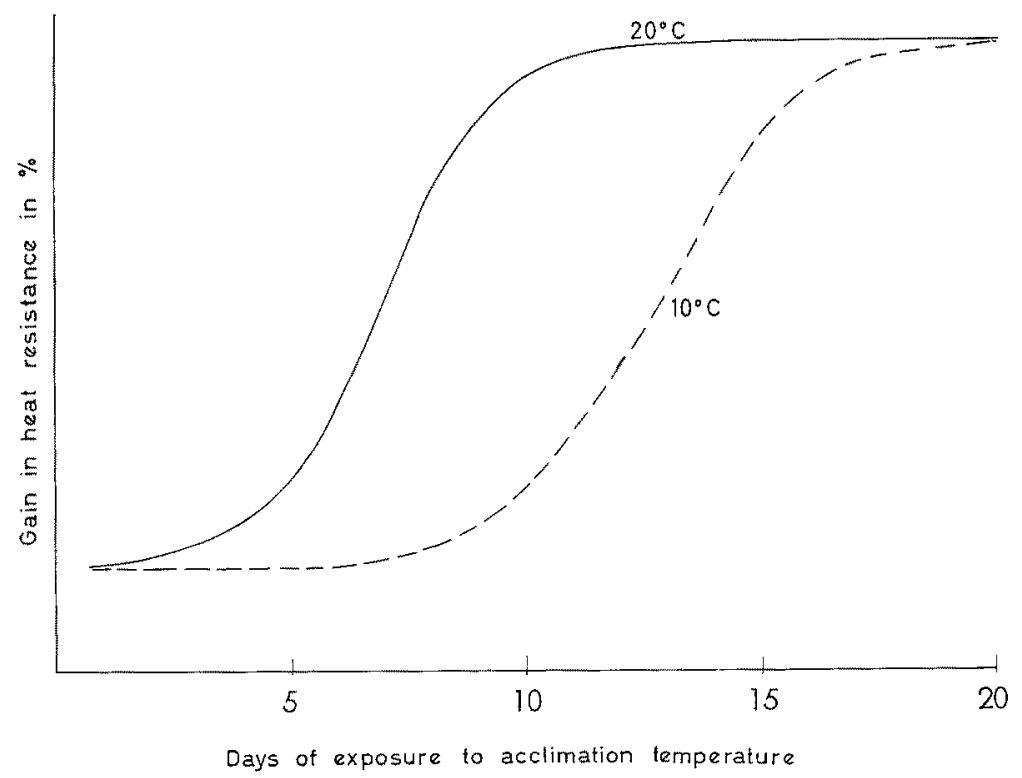

Fig. D1: Hypothetical diagram of different time courses of percentual gains in heat resistance in fish exposed to $10^{\circ}$ and $20^{\circ} \mathrm{C}$ respectively. At $10^{\circ} \mathrm{C}$ close to $100 \%$ of the artainable heat resistance is reached after about 19 days, at $20^{\circ} \mathrm{C}$ after about 11 days; the time course of acclimation is different at both temperature levels 
that the evolutionary invention of multicellularity and the subsequent development of nervous, hormonal and circulatory systems has led to an increasing degree of thermal independence from climate. I wonder whether this statement needs some specification; it is well known that unicellular organisms often display remarkable tolerances and independencies in regard to adversive environmental temperature conditions even during their active phase of life.

RoBERTS: I wish that I were able to give a more complete answer to this very fundamental question than is now possible on the basis of the experimental evidence. I can specify my statement to the extent that I mean it to apply primarily to capacity and not to resistance adaptations. It is this latter category to which I assume you are referring in speaking of thermal independence of unicellular organisms. However, I would choose to avoid the use of the term independence for unicells because they do respond to temperature change, often with little or no capacity adaptation, but of course sometimes showing remarkable ranges of thermal tolerance. - This would seem to be a good time to bring up some thoughts whid have taken form largely from the very provocative ideas recently presented by UsHakov and the experiments of Baslow \& Nigrelli (loc. cit.). One of these is the suggestion that resistance adaptations have appeared earlier on the evolutionary scene than have capacity adaptations. Another, but a related suggestion is that the thermal independence to which I have referred, represents the operation of mechanisms that have evolved with differentiation and complex organization of cells in multicellular organisms to the degree that in some of the larger, semiterrestrial crustaceans, and among vertebrates, these mechanisms now serve homeostatic functions. Therefore, they might be considered to be, in a broad sense, behavioral thermoregulations.

Precht: Eine kurze Bemerkung zu der von Herrn KinNe angeschnittenen Frage Einzeller versus Vielzeller. Sowohl Einzeller als auch Vielzeller können eine Leistungsadaptation aufweisen. Zunächst gehorcht der Stoffwechsel der RGT-Regel. Meist nach einigen Tagen macht sich dann oft eine Anpassung in dem Sinne bemerkbar, daß ein Standardstoff wechsel trotz unterschiedlicher Temperaturen angestrebt wird. Bei den höheren Tieren dürften übergeordnete Systeme an diesen Regulationen beteiligt sein (ZNS, Hormondrüsen). Wie kann sich aber eine Zelle (etwa eine Hefezelle) anpassen? Man könnte daran denken, daß die Reaktionsgeschwindigkeir der Stoffwechselprozesse zunächst mit steigender Temperatur erhöht wird, doch haben vielleicht Syntheseprozesse von nachzuliefernden Enzymen niedrigere Temperaturkoeffizienten, was dann im Laufe von Tagen zu einer Drosselung des Stoffwechsels im Sinne einer Leistungsadaptation führen könnte. Wahrscheinlich ist eine derartige Erklärung jedoch für viele Fälle zu einfach. Beim Fischgewebe (Idus idus) wird sogar die Mitochondrienzahl mit der Adaptationstemperatur geändert (Anstieg mit fallender AT; JANKOWSKY \& KORN Naturwissenschoften $52,642,1965)$. Man muß wohl auch für die einzelne Zelle Regulationssysteme annehmen, die man in Form von Reglerkreisen darstellen kann.

KINNE: There is one other point I would like to make. Have you - in addition to measuring oxygen consumption - also assessed the activity of your sunfish? It seems difficult to evaluate the differences in performance observed without considering routine swimming activity.

ROBERTS: Not in the sense of your question. During the respiration studies, the fish were kept in cylindrical vessels which were sized so that active swimming was not possible. I am sure that the respiration rates that $I$ have reported represent rates as nearly basal as one can obtain with fish. I hope that comparisons with swimming rates of respiration will be forthcoming, either from my laboratory at Amherst or from Dr. BRETr's at Nanaimo. Such experiments must be done if we are to properly assess the significance of the zones of thermal homeostasis which $I$ have reported for pumpkinseed sunfish.

PRECHT: Es ist erstaunlich, daß verwandre Arten sich hinsichtlich des Typs der Leistungsadaptation unterscheiden können. SuHrmann (Biol. Z bl. 74, 432, 1955) nannte ihre Versudastiere Carassius oulgaris. Diese zeigten eine partielle Kompensation (Typ 3), wie dies nach mehreren Autoren auch für den Goldfisch zutrifft. Später fanden E. v. BudpenBrock ( $Z$. wiss. Zool. 164, 173, 1960) und Roberts (Zool. Anz., Suppl. Bd 24, 73, 1961) bei anderen Tieren eine inverse Kompensation (Typ 5) des Sauerstoffverbrauchs. Sie arbeiteten mit C. carassius, 
Suhrmann dagegen mit großer Wahrscheinlichkeit mit C. gibelio, der östlichen Stammform des Goldfisches. Die beiden so nahe verwandten Arten kommen in hochrückigen und flachen Rassen vor.

Schmidt: Ich möchte an die Herren Roberts und Precht die Frage stellen, wie weit bei den Adaptationsversuchen die von der Temperatur abhängige, unterschiedliche Entwicklungsgeschwindigkeit berücksichtigt wird. Ich fand bei Insekten im Bereich der optimalen Entwicklungstemperatur den absolut geringsten $\mathrm{O}_{\mathrm{Q}}$-Verbrauch und damit - energetisch betrachtet den rationellsten Stoffwechsel. Bei der Untersuchung der Adaptationsphänomene, zum Beispiel bei Amphibien, könnten sich solche Befunde als Störfaktoren bemerkbar machen.

PRecht (zu SchmidT): Wir haben im allgemeinen erwachsene Tiere untersucht, bei denen mit solchen Störungen weniger $z u$ rechnen ist, es sei denn, der Lebensablauf schreitet bei kurzlebigen Tieren (etwa bei manchen Insekten) bei höheren Adaptationstemperaturen sehr schnell fort. Dann soll man die Adaptationszeiten nicht unnötig ausdehnen und dieselben Tiere möglichst zuerst an eine tiefere und dann eine höhere Temperatur, andere erst an eine höhere und dann eine tiefere Temperatur anpassen, oder dieselben Tiere sogar einem zweimaligen Wechsel der Adaptationstemperatur aussetzen. Es läßt sich dann meist erkennen, ob sektundäre Einflïsse (Hungerperioden, Altern etc.) den Adaptationseffekt verändern, da er je nach der Versuchsbedingung entweder abgeschwächt oder verstärkt wird. Man kann natürlich auch untersuchen, ob die Entwicklungsprozesse selbst eine Temperaturadaptation zeigen, wie dies zum Beispiel Grainger (Zool. Anz. 163, 267, 1959) tat. Gewöhnlich werden die Entwicklungsstadien bei konstanten Temperaturen gehalten; sie sind somit langfristig adaptiert. Dennoch maß man bei den oft untersuchten Schadinsekten relative hohe Temperaturkoeffizienten. Dies deutet auf eine geringe Adaptation der Entwicklungs- und Wachstumsprozesse hin. Es ist jedoch zu berücksichtigen, daß mande Insekten sich auch in ihrem Stoffwechsel kaum anpassen. Darum wäre es wünschenswert, Entwicklungsprozesse von solchen Arten zu untersuchen, deren Betriebsstoff wechsel eine deutliche Leistungsadaptation zeigt.

Scharf: Es war sehr eindrucksvoll für mich, zu hören, daß zwei ganz eng miteinander verwandte Carassius-Arten bereits Unterschiede zeigen. Können Sie, Herr RoserTs oder Herr PRECHT, etwas darüber sagen, wie die Unterschiede zwischen Cyclostomata und Teleosteern sind? Gibt es darüber exakte Untersuchungen?

RoвERTs: I have no knowledge of such comparisons.

Precht (zu SCHARF): Meines Wissens liegen darüber keine Untersuchungen vor.

SCHLIEPER: Ich möchte fragen, ob störende Faktoren bei der Messung thermischer Adaptationen von Fischen durch Untersuchung ihres Sauerstoffverbrauches nicht auch die größere Bewegungsaktivität und die erhöhte osmoregulatorische Arbeitsleistung in der Wärme sein können? Die Schwimmbewegungen der Versuchsfische könnten durch Rüdkenmarksquerschnitt hinter dem Gehirn weitgehend ausgeschaltet werden. Und die osmoregulatorische Arbeitsleistung könnte wohl durch Haltung der Fische in einem isotonischen Medium stark verringert und relativ konstant gehalten werden. Ist derartiges bereits versucht worden?

ROBERTS: In regard to the possibility of minimizing osmotic effects on thermal adaptations, I would like to make two comments. First, in Artemia, active metabolism requirements for ionic regulation under extreme conditions (distilled water, fresh water, saturated $\mathrm{NaCl}$ ) amounts to only 6 per cent as estimated by Croghan (J. exp. Biol. 35, 1958) for adults, and for nauplii by one of my former students, Miss $N$. Kratowch (MS unpubl.). This is an extreme example, I agrce. There is also the case of Ocypode, the ghost crab, which is reported to show large metabolic differences of about 20 per cent when stressed to extremes in osmotic environments on either side of isotonicity (FLEMISTER \& Flemister Biol. Bull. mar. biol. Lab., Woods Hole 101, 1951). In this particular case, a very excitable animal was used so I wonder what part of the observed response difference was due to osmoregulation and what part to unseen or perhaps tonic, motor activity.

Schlteper: Die Ergebnisse an Artemia dürfen wir, glaube ich, nicht zu den Vergleichen mit 
den Fischen heranziehen, da Artemia extrem euryhalin ist und eine außerordentlich niedrige Permeabilität der Außenmembranen besitzt.

RoBerts: This is certainly true for Artemia, but the point which bothers me most is that the metabolism required for osmotic work in good hypo-osmotic regulators (and certainly freshwater fishes are good hypo-osmotic regulators) should only be a small fraction of routine, resting metabolism. Yet, as you know, the literature bearing on this point is rather confusing to an interested by-stander such as myself (see also PotTs \& PARrY; Osmotic and ionic regulation in animals. Pergamon pr., Oxford, 1964). 